\title{
Sectoral Contribution to Economic Development in India: A Time-Series Co-Integration Analysis
}

\author{
Sandip SOLANKI ${ }^{1}$, Krishna Murthy INUMULA ${ }^{2}$, Asmita CHITNIS $^{3}$ \\ Received: July 03, 2020 Revised: July 19, 2020 Accepted: August 10, 2020
}

\begin{abstract}
This research paper examines the causal relationship between India's economic growth and sectoral contribution to Gross Domestic Product (GDP) and vice versa, in the short-run and long-run, over a 10 years time period. Johansen's method of cointegration is used to study the cointegration between the sectoral contributions to Indian GDP vis-à-vis India's economic growth. Further, the route of interconnection between economic growth and sectoral contribution is tested by using Vector Auto Regression (VAR) model. Special attention was given for investigating impulse responses of economic growth depending on the innovations in sectoral contribution using time-series data from 1960 to 2015. This paper highlighted a dynamic co-relationship among industrial sector contribution and agricultural sector contribution and economic development. In the long run, one percent change in industrial sector contribution causes an increase of 3.42 percent in the economic growth and an increase of 1.12 percent in the primary sector contribution, while in the short run industrial and service sector contributions showed significant impact on economic development and agriculture sector. The changing composition of sector contribution is going to be an important activity for the policymakers to monitor and control where the technology and integration of sectors play a significant role in economic development.
\end{abstract}

Keywords: Economic Growth, Economic Sectors, Econometrics Analysis, Co-integration, India

JEL Classification Code: C22, L60, O11

\section{Introduction}

India, with a GDP value of about 2.9 trillion dollar, became the seventh largest economy in the world, and looking at the buying power, India is positioned as the third biggest economy on the planet. The structural transformation of Indian economy under different policy regimes saw an uneven growth patterns in the sectoral composition causing

${ }^{1}$ First Author and Corresponding Author. Associate Professor, Symbiosis Institute of International Business (SIIB), Symbiosis International (Deemed University), (SIU), India [Postal Address: Hinjawadi, Pune - 411057, Maharashtra, India] Email: sandip.solanki@siib.ac.in

${ }^{2}$ Associate Professor, Symbiosis Institute of International Business (SIIB), Symbiosis International (Deemed University), (SIU), India. Email: dr.krishna@siib.ac.in

${ }^{3}$ Director, Symbiosis Institute of International Business (SIIB), Symbiosis International (Deemed University), (SIU), India. Email: asmitachitnis@siib.ac.in

(c) Copyright: The Author(s)

This is an Open Access article distributed under the terms of the Creative Commons Attribution Non-Commercial License (https://creativecommons.org/licenses/by-nc/4.0/) which permits unrestricted non-commercial use, distribution, and reproduction in any medium, provided the original work is properly cited. huge variations in economic growth of the country. The import substitution regime (1960-80) or the inward-looking policy regime, saw a significant decline in the agriculture contribution giving rise to non-agriculture contribution that resulted into the per-capita gross domestic product of the country to rise. Most of the economists believe that during this period of substitution regime, India's structural transformation from a primary sector to non-primary sector economy replaced the agriculture domination with nonagriculture industrial growth.

In the reform phase (period after the year 1991-92), policies of economic liberalization and subsequent impact of globalization increased India's domestic and foreign trade capabilities, which came at par with the other developing countries. Post-independence, the Indian policymakers also made conscious efforts to boost the agriculture sector with the help of green revolution and subsequent innovations in cultivation practices. In India, agriculture contribution $(14.39 \%)$ to India's economy is much higher than world's average $(6.4 \%)$ as per records of 2019. The liberalization regime (1980-2004) witnessed a steady growth (yet comparatively slower than earlier substitution regime) in 
structural transformation from agriculture to industry. The license raj system eroded the benefits of sustainable trade and led to the imperfect competition among the industrialists and even increased corruption levels across the country. The economic reforms regime (post-1991) gave more thrust to agriculture to further increase its contribution to the economy; as of now (2019) the share of Indian primary sector to the country's GDP stood at around $14 \%$. During the reforms' period (abolition of license raj system) the opening of the economy resulted in exploring the full potential of the industry by its diversification from basic traditional iron and steel to jute and automobiles. As per the year ending 2019 , the share of India's industry sector to the country's GDP stood at around 29\%, almost double of agriculture contribution.

The advancement in science and technology has created more innovative services adds to the conventional service sector, which comprises banking, finance, telecommunications, and business process outsourcing, currently regarded as the backbone contributing around $57 \%$ of the economy. With the emergence of information technology (IT) and information technology-enabled services, India has become the largest provider of the best technology manpower with a great demographic dividend, and has become one of the major IT hubs of the world. The recent development in the banking and financial services has offered more inclusive growth in the country, facilitating the much needed and easier economic reforms for financial inclusion. Because of the innovations and customer feedback loops, more employment opportunities are offered in the service sector compared to agriculture and industry. Diversification and privatization of different services such as travel, tourism, medical sectors, etc., have contributed to raise service sectors' competencies. However, the country's transformation from primary sector to tertiary sector has its own advantages and disadvantages.

India's external trade has a significant impact on the economic development of the country. The service sector contributes more to the external trade in terms of high technology exports compared to the agriculture and industrial output, namely, agricultural products, engineering goods, chemicals \& marine products, textiles, plantations, petroleum, and leather goods. The Make in India initiative which was tossed in the year 2014 by the government is a one-step forward movement to promote agriculture and industrial exports. The three major aims of this initiative are first to push up the secondary sector growth rate to $12-14 \%$ per annum, second to generate one hundred million additional manufacturing job opportunities in the country before 2022, and third to endorse secondary and allied exports.

The rate of technological change is not the same across the sectors causing uneven growth in sector wise performance and results in unbalanced economic growth in the country. In the agriculture sector, besides the very limited technological innovations, the resource-based constrains such as farmer's inability to pay back loans, lack of minimum price support by the government, abnormal cultivation practices, lack of technical knowhow, and urbanization are causing distress in the farming community. The time reversal of the role and contribution of agriculture and service sectors in India is a matter of utmost importance for the policymakers to strive for a balanced economic growth in the country. Because of rapid urbanization and changing lifestyles, there is a need for innovations to create a balanced mix of three-sector composition to provide more employment opportunities to the next generation. Therefore, there is a requirement to better understand the current sectoral composition of the country and take suitable policy decisions for the development of a balanced economic.

The paper is organized as follows: Section 2 gives a brief literature review explaining different types of research that have been led so far in various economies of the world. Section 3 details different econometric methods that are used in this study. Section 4 gives results of this study, followed by conclusions in Section 5 .

\section{Literature Review}

Scholars have tried to understand the causal association between economic growth and sectoral contributions to GDP and vice versa for different countries in the short run as well as long run. For example, in studies by Hwa (1988); Sastry, Singh, Bhattacharya, and Unnikrishnan (2003), the results inferred that the agricultural sector is still dominating and contributes significantly to the overall economic growth in general. Gollin, Parente, and Rogerson (2002) argued that agricultural productivity contributes significantly to economic development with the help of structural transformation model. The paper also highlighted that reason for slow industrialization. In yet another study,Turan Katircioglu (2006) revealed that agricultural output and economic growth are co-integrated and also have bidirectional causation among them in the long run. In a similar study, Awokuse (2009) indicted that the primary sector has emerged as very significant force for economic development in 15 emerging as well as transition countries in Africa, Asia and Latin America. In another research in China by Xuezhen, Shilei, and Feng (2010), an econometric model analysis was performed for the period 1952-2007, showing an positive connection between the primary sector and economic growth also highlighting that the primary sector is significantly contributing to economic growth. In yet another empirical study, Jatuporn, Chien, Sukprasert, and Thaipakdee (2011) using time series analysis, the paper investigated a long-run interelationship between the primary sector growth and economic growth and vice versa from 1961 to 2009 in Thailand. 
Sandip SOLANKI, Krishna Murthy INUMULA, Asmita CHITNIS /

Journal of Asian Finance, Economics and Business Vol 7 No 9 (2020) 191-200

But, there are studies in the literature where authors have denied the linkage of agriculture with economic growth. For example, Katircioglu (2004) demonstrated that, in spite of agriculture being the backbone of the North Cyprus economy, the agricultural sector does not contribute significantly to the economic development. The result also reveals that there is co-integration between real GDP and industrial output and the service sector.

Nemours' research examined the causal connection among secondary sector growth and economic development, between service sector growth and economic growth and between agricultural growth and economic growth over the short run as well as the long run. Tregenna (2008) identified that the manufacturing sector was an important sector for creating demand in the service sector as well as the economy as a whole through its strong backward linkages for the South Africa. Similarly, Szirmai (2012) showed that the secondary sector has significantly contributed to the development of the economy, but cannot be considered as an engine of economic growth; the study was conducted in 67 emerging nations and 21 advanced nations during the period 1950-2005. Matahir (2012) showed that the primary and secondary sectors are cointegrated in the long run as well as found one-way causality direction from the industrial sector to the agricultural sector over the short and long run for the period from 1970 to 2009 in Malaysia. Other researchers have also identified the significant role of various sectors in the economic development, e.g., Bhattacharya and Mitra (1989), who inferred that relative growth of income and employment in both sectors, namely, secondary and tertiary, significantly affected the nature of the agriculture-industry relationship.

Echevarria (1997) and Verner and Fiess (1999) explored the relationship between sectoral composition and economic development. Results highlighted that sectoral composition also effects the growth and vice versa. Gemmell, Lloyd, and Mathew (1998) used time-series econometric techniques for investigating linkages between agricultural, manufacturing and service GDPs (and productivity) in Malaysia. Results suggested significant impact of both manufacturing and service sectors on agricultural productivity in the long run. In other study, Block (1999) calculated macroeconomic growth multipliers resulting from income shocks to the primary sector, modern and traditional secondary sector in Ethiopia. Verner and Blunch (1999) conducted a study on three African economies and found that at least one statistically significant long-run relationship for sectoral GDP through comprising sectoral growth.

The importance of such linkages was further stressed by Gani and Clemes (2002) who revealed that growth of tertiary activities exercises a statistically significant positive effect. Moreover, results also highlighted a strong positive effect of growth in secondary sector and government expenditure on tertiary activities. Clemes, Arifa, and Gani's (2003) findings showed a robust, positive bi-directional effect of growth of tertiary sector and secondary sector of ASEAN economies. Similarly Craigwell, Downes, Greenidge, and Steadman (2008) investigated relationships between the primary sector, secondary sector and tertiary sector over the long run and short-run in Barbados over the past five decades. Results showed one cointegrating relationship in both the subperiods. Furthermore, Subramanian, Saghaian, Maynard, and Reed (2009) showed that tertiary sector was found to be the major driver of development of both sectors, namely, primary and secondary, during initial phases of development in Poland and Romania. Eddine (2010), in his empirical study, found all Tunisian economic sectors to be co-integrated and showing unidirectional movement. Rahman, Rahman, and Hai-bing's (2011) results indicated that primary and secondary sectors are the most significant factors of the GDP of Bangladesh. Interestingly, in this study, the service sector did not emerge as an influencing factor for the GDP growth; however, GDP was recognized as a most important driver for the tertiary sector growth.

Hussin and Yik (2012) undertook a study of Indian and Chinese economies. They used a time-series analysis to study the sectoral composition and its impact on the economic development. The results found that each sector has a robust, positive and substantial linear relationship with economic growth in both economies. The study was conducted over the period between 1978 and 2007. In addition, the results of multiple regression analysis showed a positive relationship between primary, secondary and tertiary sectors with the GDP per capita in both countries India and China. Sepehrdoust and Hye (2012) in their study of Iranian economy, explored the relationship between the variables gross domestic product (Y), industrial value added (IN), agricultural value added (AG), services value added (SS) and oil and gas value added ( $\mathrm{O}$ and $\mathrm{S})$. The study indicated that one percent rise in industrial value added (IN), agricultural value added (AG), services value added (SS) and Gas, caused the GDP to rise by $0.216,0.091,0.431$ and 0.156 percent, respectively, for the period 1959-2010 in Iran.

Burren and Neusser (2013) highlighted the shift of the US economy from good-producing to the service sectordriven economy. In this study, 30\% of the decline in GDP's unpredictability was due to the service sector in spite of some sectors found to be even more volatile. Singaariya and Sinha (2015) also indicated the presence of bidirectional causality between primary sector and economic growth, while the unidirectional causality between the secondary sector and economic growth and that between the primary and secondary sector in India. In another study of the Bangladesh economy, by Uddin (2015), over the period from 1980 to 2013, each 
economic sector (agriculture, industry and services) was found to have a strong, positive and significant linear relationship with the country's economic growth. The study done by Alhowaish and Al-Shihri (2015) found that there is a bidirectional causality among the sectoral output of the Saudi economy in the short run. Recently, Malikov, Qineti, Pulatov, and Shukurov (2016) indicated that agriculture still dominates in terms of employment in Uzbekistan. Islam, Ahmed, Saifullah, Huda, and Al-Islam's (2017) study used VAR model and suggested that industrial production and GDP per capita have a significant relationship with carbon emission.

Popoola, Araromi, Rafiu, and Odusina (2017) revealed that the agriculture sector makes the highest contribution to the growth of the economy, followed by the manufacturing and oil sectors, respectively, while the least contribution was made by building and construction in Nigeria. Cantore, Clara, Lavopa, and Soare (2017) used the Generalized Method of Moments (GMM) technique on 80 countries to treat the endogeneity bias for the period between 1980 and 2010. The findings highlighted that the secondary sector is an engine of economic growth. Gabriel and Santana Ribeiro (2019) observed that growth multipliers were 1.54 for primary sector, 1.80 for tertiary sector, 1.34 for modern industry, and 1.22 for traditional industry. Findings showed that intersectional connections are operated on a significantly uneven basis.Khan (2020) used simulation technique to study the Nepalese economy. The results of this study inferred that labor productivity as well as sectoral contribution have favorable effects on growth, welfare and household income of Nepal.Kumar and Paramanik (2020) showed that economic growth rate is affected positively by financial development in the long run, while Luong, Nguyen, and Nguyen (2020) revealed that economic growth indicators have negative and statistically significant impact on the shadow economy. Moreover, Ngo, Cao, Nguyen, and Nguyen (2020) highlighted that FDI is affected by size of market and Nurlanova, Omarov, and Satpayeva (2020) identified that innovative activities is most important factor affecting sustainable development

From the review of the literature it can be observed that sectoral contribution and its impact on the economic development of various nations remained a topic of most relevant research. A number of studies has been conducted in the past on various economies about this relationship. To the best of our knowledge, no study has been done in the recent past, which explores the sectorial contribution to Indian economic growth using a time-series co-integration analysis.

In this paper, an attempt has been made to study various sectoral contributions to the Indian economic growth using co-integration analysis method for the time period from 1960 to 2015.

\section{Data and Methods}

\subsection{Data and Scope}

This research uses time-series annual data from 1960 to 2015 on four economic indicators, namely, GDP per capita in current US dollars, agriculture value added (\% of GDP), industry value added ( $\%$ of GDP), and services value added ( $\%$ of GDP)", collected from World Bank open data website (data.worldbank.org). Since independence, India has undergone a sectoral shift from agrarian economy to a service-based economy in spite of the majority of rural population is engaged in agriculture and semi-agricultural practices, which is keeping the industry growth performance to a moderate level during the study period.

This research studies the causal association between economic development and sector contribution and vice versa. This study uses an endogeneity framework, which facilitates each variable as a study variable or dependent variable, so that the interrelationships among the variables can be captured through the causality flow between the variables.

\subsection{Econometric Method}

This study uses Johansen's method $(1988,1991)$ to study the cointegration between the sectoral contributions to Indian GDP vis-à-vis economic growth. In addition to Johansen's method, the Engle-Granger causality technique is also employed to determine the direction of the causality by using the vector auto regression (VAR) framework. The study of cointegration requires that the time-series data are assumed to be stationary and hence it is tested for possible non-stationary. Augmented Dickey Fuller (ADF) test is used as well to confirm the stationary and non-stationary of the level and first differenced variables. The selection of lag length is based on the best of three information criterion scores, namely,Akaike Information criterion (AIC), Schwartz Bayesian criterion (BIC), and Hannan-Quinn criterion (HQC).

The simultaneous equation system (VAR) facilitates each variable to be considered as endogenous on each other for determining the significant impact of each variable on each other. The direction of the causal relations between the study variables is also tested for determining which variable can cause the other variables, and the information of causal flow between the variables is at most important in model building and prediction. The following VAR framework is used in this study to explore the relationship among the agriculture, industry and services sectors of the Indian economy, with economic growth. 


$$
\begin{aligned}
G D P_{t}= & C_{1}+\sum_{i=1}^{k} a_{1 i} G D P_{t-i}+\sum_{i=1}^{k} b_{1 i} A G C L_{t-i} \\
& +\sum_{i=1}^{k} c_{1 i} I N D U S_{t-i}+\sum_{i=1}^{k} d_{1 i} S E R V_{t-i}+e_{1 t} \\
A G C L_{t}= & C_{2}+\sum_{i=1}^{k} a_{2 i} G D P_{t-i}+\sum_{i=1}^{k} b_{2 i} A G C L_{t-i} \\
& +\sum_{i=1}^{k} c_{2 i} I N D U S_{t-i}+\sum_{i=1}^{k} d_{2 i} S E R V_{t-i}+e_{2 t} \\
\text { INDUS }_{t}= & C_{3}+\sum_{i=1}^{k} a_{3 i} G D P_{t-i}+\sum_{i=1}^{k} b_{3 i} A G C L_{t-i} \\
& +\sum_{i=1}^{k} c_{3 i} I N D U S_{t-i}+\sum_{i=1}^{k} d_{3 i} S E R V_{t-i}+e_{3 t} \\
\text { SERV }= & C_{4}+\sum_{i=1}^{k} a_{4 i} G D P_{t-i}+\sum_{i=1}^{k} b_{4 i} A G C L_{t-i} \\
& +\sum_{i=1}^{k} c_{4 i} I_{N D U S_{t-i}}+\sum_{i=1}^{k} d_{4 i} S E R V_{t-i}+e_{4 t}
\end{aligned}
$$

Where GDP is the per-capita economic growth, AGCL is the contribution of agriculture to the economy, INDUS is the contribution of industry to the economy, and SERV is the service sector contribution to the economy. Where " $\mathrm{t}$ " is the current time period and "t-i" indicates the time with lag $i$, and "the error term e which is assumed to be normally distributed with mean zero and time invariant covariance matrix $\sigma$ ". The direction of causality is tested up to lag 10 between all the four variables.

\section{Results and Discussion}

\subsection{Trends of Time Series Variables}

The time-series trend of the data variables are showed in Figure1, over the study period. It can be seen that the value added from agriculture and service sectors is in opposing direction as the agriculture value added, continuously decreasing from $45 \%$ to $15 \%$, whereas the service sector value addition increases significantly from $36 \%$ to $53 \%$. The increase in economic growth can be seen in the post-reform period that is after 1991-92, whereas the industry value addition has increased from $18 \%$ to $34 \%$. Both industry and service sectors show steady increase in growth, while the agriculture sector declines continuously during the study period (see Figure 1).

\subsection{Stationary Time-Series Analysis}

All the data variables are converted to natural logarithmic scale (log level) to mitigate the heterogeneity and scale affect. Both level and first difference variables are tested by ADF test statistic under the assumption that the underlying variable is non-stationary. The results from Table 1 shows that data variables tested without constant, with constant, and constant with trend, respectively, confirming the non-stationary level form. But, after first difference they became stationary. The next step is to see whether the per-capita economic growth and sector value addition are co-integrated or not.

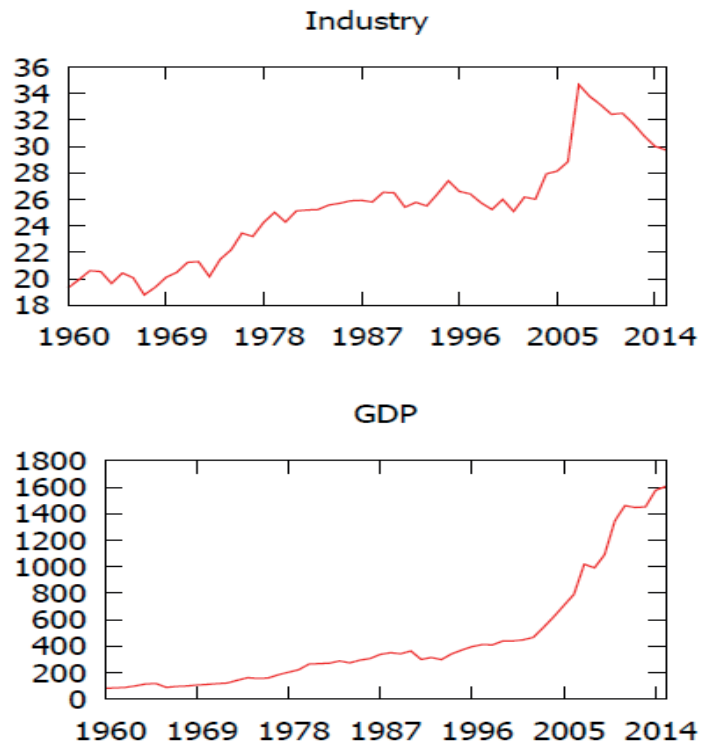

Figure 1: Time series Graph 
Table 1: ADF Test

\begin{tabular}{|l|c|c|c|}
\hline Level Form & P Value & $\begin{array}{c}\text { First } \\
\text { Difference }\end{array}$ & P Value \\
\hline \multirow{2}{*}{ I_GDP } & $\begin{array}{c}0.1650 .528 \\
0.656\end{array}$ & d_I_GDP & 0.02 \\
& & & 0.01 \\
I_AGCL & 0.421 & & 0.05 \\
\hline \multirow{2}{*}{ I_INDUS } & 0.898 & d_I_AGCL & 0.00 \\
& 0.785 & & 0.00 \\
& 0.558 & & 0.03 \\
\hline \multirow{2}{*}{ I_SERV } & 0.760 & d_ I_INDUS & 0.00 \\
& 0.823 & & 0.00 \\
& 0.458 & & \\
& 0.660 & d_I_SERV & 0.00 \\
& 0.523 & & 0.00 \\
\hline
\end{tabular}

Table 2: Lag selection \& Causality between variables.

\begin{tabular}{|l|c|c|c|c|c|}
\hline lags & loglik & $\mathbf{p}$ Value & AIC & BIC & HQC \\
\hline 1 & 430.80 & & -16.11 & $-15.35^{*}$ & -15.82 \\
\hline 2 & 454.24 & 0.00007 & -16.40 & -15.03 & $-15.88^{*}$ \\
\hline 3 & 471.66 & 0.00418 & $-16.45^{*}$ & -14.48 & -15.70 \\
\hline 4 & 485.49 & 0.03467 & -16.37 & -13.79 & -15.38 \\
\hline 5 & 494.43 & 0.33044 & -16.09 & -12.91 & -14.87 \\
\hline
\end{tabular}

*Indicate the best

\subsection{Lag Selection and Direction of Causality}

It can be seen from Table 2 that, out of all the three information criterion, Akaike criterion (AIC), Hannan-Quinn criterion (HQC) and Schwarz Bayesian criterion (BIC), AIC had given the lowest value at lag 3 , therefore the period of lag 3 is selected. Table 2 gives the details of lag length and causality. The causal relations are tested for up to $10 \mathrm{lag}$ periods using the Vector Auto Regression proposed by Engel and Granger, wherein the null hypothesis is where economic growth does not (Granger) cause sectoral contribution and vice versa.

From Table 2, it can also be observed that at different lag periods, there exists a bi-directional causality running from economic growth to sector contribution and vice-versa. Up to the lag 10, economic growth is causing agriculture contribution, up to lag 4 economic growth is causing industry contribution and at lag 2 economic growth is causing service sector value addition. At lag period 2, all the sectors' contribution (value addition) is causing economic growth. The bi-directional causal relationship between economic growth and sector contribution implies that balanced growth between the sectors is important to determine the overall economic growth. The inter-causality between the sectors is also visible from the results.

Up to lag 4, industry sector is causing agriculture growth, while at higher lags from 4 to 8 , agriculture is causing industry contribution meaning that both the agriculture and industry sectors have bi-directional causality between them. Up to lag 10, the service sector contribution is causing agriculture value addition, and at lag 2, agriculture value addition is causing service sector growth, which implies that both agriculture and service sectors are having bi-directional causality between them. There exists a uni-directional causality running from the service sector to the industry sector meaning that service sector growth (Granger) causes industry sector growth. This implies that changes in service sector contribution are useful for predicting changes in industry contribution to economic growth. Up to the period lag 10, there exists no causality from industry to service sector, which means that the industry sector does not (Granger) causes growth in service sector growth. Thus, the hypothesis of economic growth not (Granger) causing the sectoral contribution and vice versa has been rejected.

\subsection{Test for Co-integration}

Table 3 results show that both the Johansen trace test and maximum Eigenvalues support the rejection of the null hypothesis, implying that there are no co-integrating relations in the system. Trace and Lmax tests indicate that there exist two co-integrating equations in the system to explain economic growth having a long run equilibrium relation with the sector value addition to GDP. In the long run, economic growth and all the three sectors move together so that any deviations caused by the shock in the system will have a tendency to restore back to equilibrium. If the variables are co-integrated, then we can measure the short-run relationship by using Vector Error Correction Model (VECM) to capture the speed of the adjustment to the equilibrium.

From the above normalized co-integrating equation $\mathrm{CE} 1$ and CE2, it can be seen that economic growth is positively influenced by industrial sector contribution and inversely related to service sector contribution. From the results it is concluded that $1 \%$ change in industrial sector contribution causes the economic growth to increase by about $3.42 \%$ while at the same time inducing an increase in the agriculture sector contribution by $1.12 \%$, though the contribution is minimum but significant in the long run. Similarly, a $1 \%$ change in service sector contribution causes the economic growth to decrease by about $6.39 \%$ while causing a reduction in agriculture sector contribution by $2.08 \%$ in the long run. 
Sandip SOLANKI, Krishna Murthy INUMULA, Asmita CHITNIS /

Table 3: Johansen's Co-integration Test

\begin{tabular}{|l|c|c|c|}
\hline Rank & Eigenvalues $\left(\boldsymbol{\lambda}_{\mathrm{i}}\right)$ & Trace Test P-value & Lmax Test P-value \\
\hline 0 & 0.6694 & $87.816[0.0000]$ & $58.674[0.0000]$ \\
\hline 1 & 0.3989 & $29.142[0.049]^{*}$ & $24.056[0.0166]^{*}$ \\
\hline 2 & 0.0914 & $0.004[0.9481]$ & $0.004[0.9482]$ \\
\hline
\end{tabular}

*Indicates two co-integrating equation.

\begin{tabular}{|l|c|c|c|c|c|}
\hline & I_GDP & I_AGCL & I_INDUS & I_SERV & $\begin{array}{c}\text { Constatnt (standard } \\
\text { errors in parenthesis) }\end{array}$ \\
\hline$\beta$ Coefficients: & & & & & \\
\hline CE1 & 1.00 & 0.00 & $-3.42^{*}(0.38)$ & $6.39^{*}(0.75)$ & $4.12^{*}(2.10)$ \\
\hline CE2 & 0.00 & 1.00 & $-1.12^{*}(0.18)$ & $2.08^{*}(0.16)$ & $3.36^{*}(0.79)$ \\
\hline
\end{tabular}

\begin{tabular}{|l|c|c|c|c|}
\hline & I_GDP & I_AGCL & I_INDUS & $\begin{array}{c}\text { I_SERV (P-values in } \\
\text { parenthesis) }\end{array}$ \\
\hline a Coefficients: & $-0.14^{*}(0.05)$ & $-0.11^{* *}(0.00)$ & $0.08(0.00)$ & $0.01(0.54)$ \\
\hline & $-0.43^{*}(0.05)$ & $-0.35^{*}(0.00)$ & $0.26^{*}(0.00)$ & $0.04(0.54)$ \\
\hline
\end{tabular}

Short-Run Coefficients:

\begin{tabular}{|l|c|c|c|c|}
\hline d_IGDP_1 & $0.13(0.42)$ & $-0.09(0.10)$ & $0.13^{*}(0.05)$ & $0.03(0.51)$ \\
\hline d_IGDP_2 & $0.11(0.1)$ & $0.04(0.48)$ & $-0.03(0.67)$ & $-0.01(0.81)$ \\
\hline d_IServ_1 & $-2.62^{*}(0.03)$ & $-1.02^{*}(0.02)$ & $0.68(0.18)$ & $0.25(052)$ \\
\hline d_IServ_2 & $-0.47(0.70)$ & $0.05(0.90)$ & $0.14(0.79)$ & $-0.17(0.69)$ \\
\hline d_II dus_1 & $-2.35^{*}(0.01)$ & $-0.89^{*}(0.00)$ & $0.60(0.11)$ & $0.14(0.63)$ \\
\hline d_IIndus_2 & $-0.50(0.58)$ & $-0.41(0.23)$ & $0.51(0.21)$ & $-0.05(0.86)$ \\
\hline d_IAgcl_1 & $-2.86(0.01)$ & $-1.28^{*}(0.00)$ & $0.81^{* *}(0.08)$ & $0.33(0.36)$ \\
\hline d_IAgcl_2 & $-1.39(0.24)$ & $-0.47(0.28)$ & $0.55(0.30)$ & $0.07(0.85$ \\
\hline
\end{tabular}

${ }^{*}$ at $5 \%$ \& ${ }^{* *}$ At $10 \%$ Level of Significance; CE:Co-integrating Equation

The error correction terms $(-0.14$ and -0.43$)$ are negative and significant. The speed of adjustment to the long run equilibrium is restored by around $14 \%$ in case of economic growth and $43 \%$ in case of agriculture sector contribution. However, in the short run, industrial and service sector contribution show significant (Wald test) impact on economic growth and agriculture sector contribution.

\subsection{Impulse Response}

From Figure 2 it can be seen that impulse responses generated over 10 years by Cholesky ordering show that one standard deviation shock to agriculture sector results in instant decline in its contribution followed by moderate increase and stable performance over the next 10 years.
While shock to agriculture sector results in negative growth in economy, industrial and service sector contribution. A one standard deviation (SD) shock to industry marks in negative growth in the overall economy, industry itself and service sector growth. Shock to the industry sector results in positive development in agriculture sector contribution. A one standard deviation (SD) shock to service sector contribution marks in negative growth in both the economy and agriculture sectors. Shock to the service sector results in positive development in service and industry sector contribution. In the next 10 years' time period, one standard deviation shock to economic growth results in positive development in agriculture and economic development, negative and decreased performance in service and industry sector contribution respectively. 

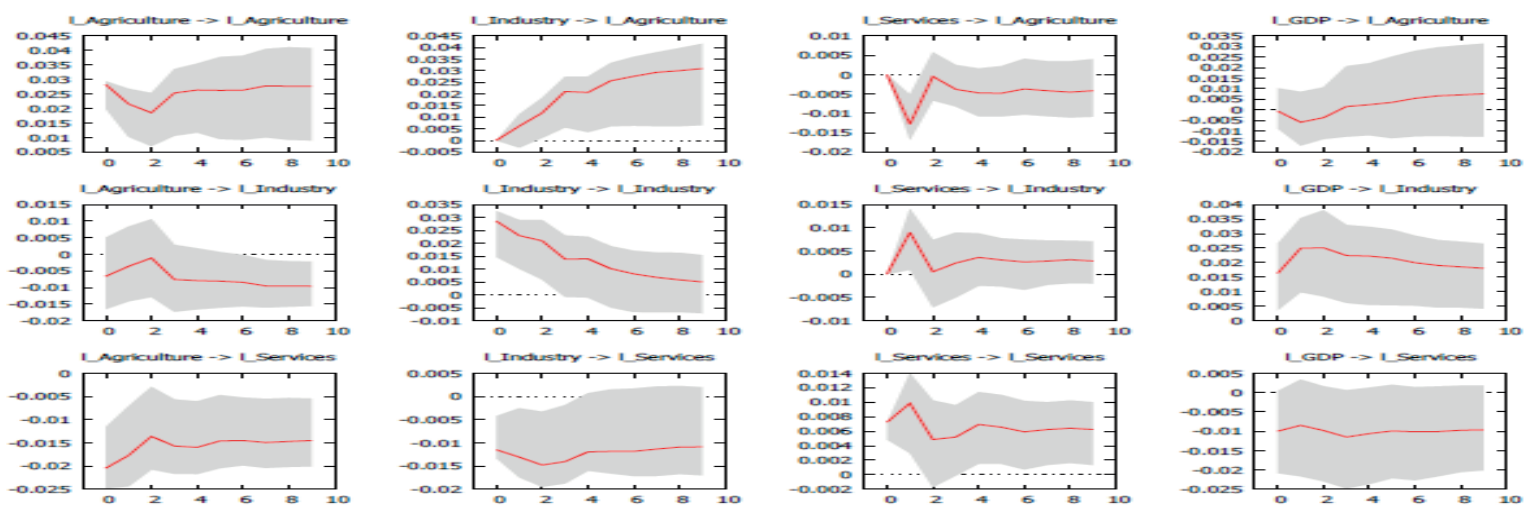

industery $\rightarrow>$ GDP
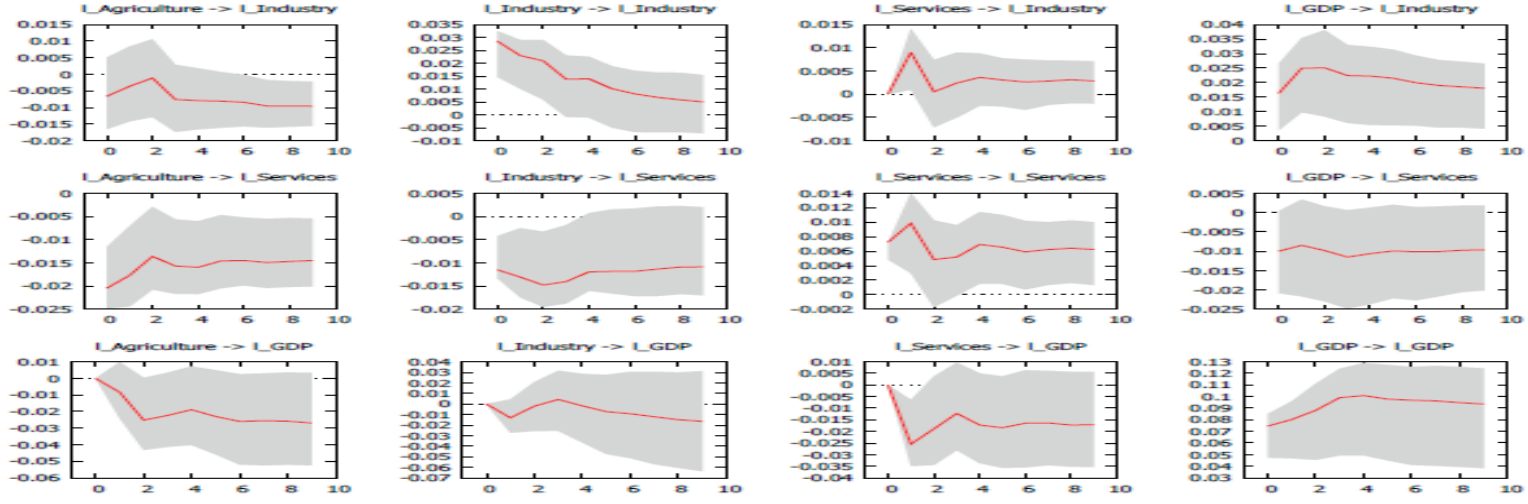

Figure 2: Impulse Response Graph

\section{Conclusion}

The structural transformation of the Indian economy under different policy regimes saw an uneven growth patterns in the sectoral composition causing huge variations in economic growth. Post-independence, the Indian policymakers also made conscious efforts to boost the agriculture sector with the help of the green revolution and subsequent innovations in cultivation practices. The liberalization regime (1980-2004) witnessed a steady growth (yet comparatively slower than earlier substitution regime) in structural transformation from primary sector to secondary sector. After the economic reforms, the roles of agriculture and service sectors became interchangeable. As of now, the Indian economy is deriving most of its contribution from the service sector followed by industry and from agriculture, the lowest sector. Bi-directional causality exists, running from economic development to sector contribution and viceversa. Results have also found two co-integrating equations in the system to explain economic growth, which is having a long-run equilibrium relation with the sector value addition to GDP. It is observed that a $1 \%$ change in industrial sector contribution triggers the economic development to increase by about $3.42 \%$, while at the same time, inducing a rise in the primary sector contribution by $1.12 \%$ in the long run. In the short run, industrial and service sector contribution is significantly affecting by economic development and the agriculture sector. Going forward, the composition of sectoral contribution will be an important activity to monitor and control where the technology and integration of sectors will certainly play an important role in the economic growth.
Thus, as explored above, all the three sectors of the economy are significantly associated with one another and, if government makes any strategic decision in anyone of these sectors, it would affect people's income and economy as a whole quite significantly. Moreover, as and when the government plans new strategies to appeal for higher FDI into agriculture, industry and service sectors, it would be worthwhile to look into evolving equations between sectoral contribution to GDP and its impact on the economic growth as revealed in this study.

\section{References}

Alhowaish, A. K., \& Al-Shihri, F. S. (2015). Dynamic Relationship between Sectoral Output and Economic Growth in Saudi Arabia: Evidence from Time Series Data Analysis. International Journal of Arts \& Sciences, 8(4), 415-422.

Awokuse, T. O. (2009). Does agriculture really matter for economic growth in developing countries? 2009 Annual Meeting, July 26-28, 2009, Milwaukee, Wisconsin 49762, Agricultural and Applied Economics Association.

Bhattacharya, B. B., \& Mitra, A. (1989). Industry-agriculture growth Rates: Widening disparity: An explanation. Economic and Political Weekly, 24(34), 1963-1970. https://www.jstor. org/stable/4395267

Block, S. A. (1999). Agriculture and economic growth in Ethiopia: growth multipliers from a four-sector simulation model. Agricultural Economics, 20(3), 241-252.

Burren, D., \& Neusser, K. (2013). The role of sectoral shifts in the decline of real GDP volatility. Macroeconomic Dynamics, 17(3), 477-500. 
Sandip SOLANKI, Krishna Murthy INUMULA, Asmita CHITNIS /

Cantore, N., Clara, M., Lavopa, A., \& Soare, C. (2017). Manufacturing as an engine of growth: Which is the best fuel? Structural Change and Economic Dynamics, 42, 56-66. https:// doi.org/10.1016/j.strueco.2017.04.004

Clemes, M. D., Arifa, A., \& Gani, A. (2003). An empirical investigation of the spillover effects of services and manufacturing sectors In ASEAN countries. Asia Pacific Development Journal, 10(2), 29-40.

Craigwell, R., Downes, D., Greenidge, K. C. D., \& Steadman, K. (2008). Sectoral output, growth and economic linkages in the Barbados economy over the past five decades. Euro-American Association of Economic Development, 8(2), 123-136.

Echevarria, C. (1997). Changes in sectoral composition associated with economic growth. International Economic Review, 38(2), 431-452.

Eddine Chebbi, H. (2010). Agriculture and economic growth in Tunisia. China Agricultural Economic Review, 2(1), 63-78.

Gabriel, L. F., \& Santana Ribeiro, L. C. de (2019). Economic growth and manufacturing: An analysis using Panel VAR and intersectoral linkages. Structural Change and Economic Dynamics, 49, 43-61.

Gani, A., \& Clemes, M. D. (2002). Services and economic growth in ASEAN economies. ASEAN Economic Bulletin, 19(2), 155-169.

Gani, A., \& Clemes, M. D. (2010). Services and economic growth in Pacific Island countries. International Journal of Development Issues, 9(2), 113-130.

Gemmell, N., Lloyd, T., \& Mathew, M. (1998). Dynamic sectoral linkages and structural change in a developing economy. Discussion Papers 98/3. University of Nottingham, Nottingham, England.

Gollin, D., Parente, S., \& Rogerson, R. (2002). The role of agriculture in development. The American Economic Review, 92(2), 160-164.

Hussin, F., \& Yik, S. Y. (2012). The contribution of economic sectors to economic growth: the cases of China and India. Research in Applied Economics, 4(4), 38-53.

Hwa, E.C. (1988). The contribution of agriculture to economic growth: some empirical evidence. World Development, 16(11), 1329-1339.

Islam, M. Z., Ahmed, Z., Saifullah, M. K., Huda, S. N., \& AlIslam, S. M. (2017). CO2 Emission, Energy Consumption and Economic Development: A Case of Bangladesh.Journal of Asian Finance, Economics and Business, 4(4), 61-66. http:// dx.doi.org/10.13106/jafeb.2017.vol4.no4.61

Jatuporn, C., Chien, L.H., Sukprasert, P., \& Thaipakdee, S. (2011). Does a long-run relationship exist between agriculture and economic growth in Thailand. International Journal of Economics and Finance, 3(3), 227-233.

Katircioglu, S. (2004). Co-Integration and Causality between GDP, Agriculture, Industry and Services Growth in North Cyprus:
Evidence from Time Series Data. Review of Social, Economic \& Business Studies, 5(6), 173-187.

Khan, M. A. (2020). Cross sectoral linkages to explain structural transformation in Nepal. Structural Change and Economic Dynamics, 52, 221-235. https://doi.org/10.1016/j. strueco.2019.11.005

Kumar, K., \& Paramanik, R. N. (2020). Nexus between Indian Economic Growth and Financial Development: A Non-Linear ARDL Approach. Journal of Asian Finance, Economics, and Business, 7(6), 109-116. https://doi.org/10.13106/jafeb.2020. vol7.no6.109

Luong, T. T. H., Nguyen, T. M., \& Nguyen, T. A. N. (2020). Rule of Law, Economic Growth and Shadow Economy in Transition Countries. Journal of Asian Finance, Economics, and Business, 7(4), 145-154. https://doi.org/10.13106/jafeb.2020.vol7. no4.145

Malikov, N., Qineti, A., Pulatov, A., \& Shukurov, S. M. (2016). The Role of Agriculture in Economic Development of Uzbekistan. SSRN Electronic Journal. DOI: 10.2139/ssrn.2924343

Matahir, H. (2012). The empirical investigation of the nexus between agricultural and industrial sectors in Malaysia. International Journal of Business and Social Science, 3(8), 225-231. https://ijbssnet.com/journals/Vol_3_No_8_Special_ Issue_April_2012/26.pdf

Ngo, M. N., Cao, H. H., Nguyen, L. N., \& Nguyen, T. N. (2020). Determinants of Foreign Direct Investment: Evidence from Vietnam.Journal of Asian Finance, Economics, and Business, 7(6), 173-183. https://doi.org/10.13106/jafeb.2020.vol7. no6.173

Nurlanova, N. K., Omarov, A. K., \& Satpayeva, Z. T. (2020). Methodological Approaches to Estimation of Economic Growth and Sustainable Development: Kazakhstan's Experience. Journal of Asian Finance, Economics, and Business, 7(4), 317324. https://doi.org/10.13106/jafeb.2020.vol7.no4.317

Popoola, O. P., Araromi, A. A., Rafiu, A. A., \& Odusina, M. T. (2017). Modelling of Gross Domestic Product of Some Sectors of Nigeria Economy in The Presence of Autocorrelation. Annals. Computer Science Series, 15(1), 77-81.

Rahman, M. M., Rahman, M. S., \& Hai-bing, W. U. (2011). Time series analysis of causal relationship among gdp, agricultural, industrial and service sector growth in Bangladesh. China-USA Business Review, 10(1),9-15.

Sastry, D. V.S., Singh, B., Bhattacharya, K., \& Unnikrishnan, N. K. (2003). Sectoral linkages and growth prospects: Reflections on the Indian economy. Economic and Political Weekly, 38(24), 2390-2397.

Sepehrdoust, H., \& Hye, Q. M. A. (2012). An Empirical Study of Inter-sectoral Linkages and Economic Growth. Trends in Applied Sciences Research, 7(7), 494-504.

Singaariya, \& Sinha, N. (2015). Relationships among per capita GDP, agriculture and manufacturing sectors in India. Journal of Finance and Economics, 3(2), 36-43. 
Subramanian, V., Saghaian, S., Maynard, L. J., \& Reed, M. (2009). Sectoral Growth Interdependencies and the Role of Agriculture in Poland and Romania. Journal of Food Distribution Research, 40(1), 1-9.

Szirmai, A. (2012). Industrialisation as an engine of growth in developing countries, 1950-2005. Structural Change and Economic Dynamics, 23(4), 406-420.

Tregenna, F. (2008). Sectoral engines of growth in South Africa: An analysis of services and manufacturing. WIDER Working Paper Series RP2008-98. World Institute for Development Economic Research (UNU-WIDER),Helsinki, Finland.

Turan Katircioglu, S. (2006). Causality between agriculture and economic growth in a small nation under political isolation: A case from North Cyprus. International Journal of Social Economics, 33(4), 331-343.
Uddin, M. M. M. (2015). Causal relationship between agriculture, industry and services sector for GDP growth in Bangladesh: An econometric investigation. Journal of Poverty, Investment and Development, 8, 124-129.http://citeseerx.ist.psu.edu/viewdoc/ download?doi=10.1.1.676.6370\&rep=rep1\&type $=$ pdf

Verner, D., \& Blunch, N.H. (1999). Sector growth and the dual economy model: Evidence from Cote d'Ivoire, Ghana, and Zimbabwe. Washington, DC: The World Bank.

Verner, D., \& Fiess, N. M. (1999). Intersectoral dynamics and economic growth in Ecuador. Washington, DC: The World Bank.

Xuezhen, W., Shilei, W., \& Feng, G. (2010). The relationship between economic growth and agricultural growth: The case of China.In: 2010 International Conference on E-Business and E-Government. IEEE. DOI: 10.1109/ICEE.2010.1330 